\title{
Harvest Index and Straw Yield of Five Classes of Wheat
}

Jing Dai ${ }^{\mathrm{a}}$, Brent Bean ${ }^{\mathrm{b}}$, Bradford Brown ${ }^{\mathrm{c}}$, William Bruening ${ }^{\mathrm{d}}$, Jeff Edwards ${ }^{\mathrm{e}}$, Mike Flowers ${ }^{\mathrm{f}}$, Russell Karow ${ }^{\mathrm{f}}$, Chad Lee ${ }^{\mathrm{d}}$, Gaylon Morgan ${ }^{\mathrm{b}}$, Michael Ottman ${ }^{\mathrm{g}}$, Joel Ransom ${ }^{\mathrm{h}}$, Jochum Wiersma $^{i^{*}}$

${ }^{\mathrm{a}}$ Wayne State University, ${ }^{\mathrm{b}}$ Texas A\&M University, ${ }^{\mathrm{c}}$ University of Idaho, ${ }^{\mathrm{d}}$ University of Kentucky, ${ }^{\mathrm{e}}$ Oklahoma State University, ${ }^{\mathrm{f}}$ Oregon State University, ${ }^{\mathrm{g}}$ University of Arizona, ${ }^{\mathrm{h}}$ North Dakota State, ${ }^{\mathrm{i}}$ University of Minnesota

* Corresponding author (wiers002@umn.edu, fax: 218-281-8603) 


\begin{abstract}
Wheat straw is a potential cellulosic feedstock for bioethanol. This study was conducted to evaluate straw yield potential and its relationship with grain yield for wheat (Triticum spp.) grown in the United States. The specific objective was to determine if differences in straw yield and harvest index (HI) exist between and within regions and/or wheat classes. Using on-going variety performance trials in eight states, a total of 255 varietal trial entriess from five classes of wheat were surveyed for above-ground biomass. Averaged over all wheat classes and regions the HI was 0.45. Soft red winter wheat in Kentucky had, on average, the highest HI and lowest straw yield among regions and wheat classes. Soft white winter wheat under irrigation in the Pacific Northwest produced the highest straw yield. Hard red winter wheat in the southern plain states of Texas and Oklahoma had, on average, the lowest HI. Differences in the amount of precipitation and cultivars were the major contributors to the variation detected within wheat classes. The amount of wheat straw available as cellulosic feedstock in a state or wheat class can be estimated using the grain yield estimates provided by the National Agricultural Statistics Service and the class specific HI.
\end{abstract}

\title{
Keywords
}

Wheat, harvest index, straw yield, biomass

\section{Abbreviations}


DW, durum wheat; HI, harvest index; HRSW, hard red spring wheat; HRWW, hard red winter wheat; SRWW, soft red winter wheat; SWSW, soft white spring wheat; SWW, soft white wheat; SWWW, soft white winter wheat; SGI, Sun Grant Initiative.

\section{Introduction}

As fossil fuel resources are expected to diminish, the development of a large bioenergy economy has been proposed as an alternative to the current fossil fuel dependent energy system. Bioethanol, a renewable fuel, can reduce dependence on fossil fuels and decrease the net emissions of carbon dioxide [1] and [2]. Large-scale production of bioethanol is often criticized for using food sources including corn and other grains as raw material [3]. Crop residues such as wheat straw and corn stover will need to become an increasingly important source of cellulosic feedstock for bioethanol [4].

An estimated 90.5 million ha of wheat (Triticum spp..) was planted in the United States in the four year period of 2012 to 2015 [5]. The material suitability, compatibility with handling infrastructures, and processing technology of wheat straw has been well studied [6], [7], and [8]. However, the productivity of wheat straw has not been characterized across regions, climates, and wheat classes. Straw is produced from three species, six classes, and hundreds of cultivars of wheat grown under a wide range of environmental conditions in the United States [9]. In order to successfully manage wheat straw as a commodity and to help position it in the biofuel industry, it is crucial to establish a geospatial database of straw yield and to understand the relations among biomass, grain yield, and straw yield.

Harvest index (HI), defined as the grain yield of a wheat crop expressed as the decimal fraction of aboveground biomass production, indicates directly the allocation of biomass to grain and indirectly the partitioning between grain and straw production [10] and [11]. HI values allow 
for convenient prediction of straw yields as grain yield data are readily available for most if not all wheat producing regions of the USA at the county level. Representative HI values for modern varieties of wheat generally fall within the range of 0.3 to 0.6 [12]. The observed progressive increase in wheat $\mathrm{HI}$ over the past decades is mainly a result of the introduction of dwarfing genes which reduced straw length and increased grain yield potential and response to nitrogen fertilizer due to reduced lodging [12] and [13]. A number of studies have demonstrated that $\mathrm{HI}$ is affected by genetic variations within certain cereal class and environmental variations within certain climate region. Larsen et al. found that the highest yielding winter wheat cultivars yielded more than 50\% more straw and over 30\% more glucose and xylose than the lowest yielding ones [1]. Engel at al. reported significant effects of cultivars, water regimes, and $\mathrm{N}$ levels on $\mathrm{HI}$ in hard red spring wheat [14]. HI was also known to be affected by abiotic stresses and sowing dates [15] and [16].

A collaborative effort, funded by Sun Grant Initiative [17], was undertaken to better understand the potential of wheat straw yield as a feedstock for cellulosic ethanol across the United States. Given the limited funding for this work, data were gathered from existing and ongoing variety evaluation trials in each of the participating states. Consequently only regionally adapted varieties were represented in the respective trials and few if any varieties were shared among trial locations. The specific objective of this survey was to investigate if differences in straw yield and HI exist among and within wheat classes. The purpose of the study was not to compare wheat cultivars per se, but rather to obtain an initial idea of the amount of variability among wheat classes and production regions. 


\section{Materials and methods}

The aboveground biomass, grain yield, and straw yield of 12 varietal trial entries of durum wheat (DW; Triticum durum), 40 entries of hard red spring wheat (HRSW; T. aestivum), 14 entries of hard red winter wheat (HRWW; T. aestivum), 174 entries of soft red winter wheat (SRWW; T. aestivum), three entries of soft white spring wheat (SWSW; T. aestivum), and 12 entries of soft white winter wheat (SWWW; T. aestivum) were surveyed in eight states (AZ, ID, KY, MN, ND, OK, OR, and TX) of the United States from 2008 to 2010 (Table 1 and 2). Five out of the six US wheat classes were included in the survey: DW, HRSW, HRWW, SRWW, and soft white wheat (SWW). The soft white class was divided in two subclasses (SWSW and SWWW) based on growth habit. These varietal trial entries were represented in multiple location-years. All location-years were replicated three or four times with the exception of Oklee MN which was replicated three times in 2009 and 2010 but only two times in 2008 (Table 1). A total of 1858 observations were collected for 255 varietal trial entries across all location-years.

Table 1 here.

Table 2 here.

Agricultural experiment stations, as part of the Land-Grant University system across the US, conduct field crop trials annually using replicated small-plot trials. These trials are conducted under authority granted by the Hatch Act of 1877 to conduct performance trials on farm crops and interpret the data to the public. Individual plots or experimental units in the trials used to collect the data presented in this study varied from 4.1 to $7.4 \mathrm{~m}^{2}$ among cooperators. Each experimental unit contained one entry and was managed using locally appropriate production practices to maximize grain yield. Grain yield and above ground biomass data used 
in this study was collected by one of two methods (Table 2). In the first method, above ground biomass was estimated by hand harvesting a randomly selected quadrat within each experimental unit as the crop reached the harvest ripe stage and weighed. The area harvested varied from 0.14 to $0.16 \mathrm{~m}^{2}$ among cooperators. Plants were cut off just above the soil surface and the cutting height ranged between 2 to $7 \mathrm{~cm}$. Harvested bundles were threshed with a stationary thresher and the harvested grain was weighed. Straw yield was calculated by subtracting the weight of the grain from the total biomass weight. In the second method, the whole experimental unit was harvested with a small plot combine and the straw was collected behind the combine and weighed immediately following the mechanical harvest. . Total biomass was calculated as the sum of the straw and grain weights. The HI value was obtained by dividing the grain yield by the aboveground biomass of the sample in either sampling method.

The potential bias between and within the two sampling methods is less than $4 \%$ of the total length of the plant which could result in $1 \%$ variation in $\mathrm{HI}$ (data now shown). Therefore the grain yield and above ground biomass data collected for this study is robust and can be combined despite having two different sampling methods and having the variation in the reported height of the header of the combines used to harvest whole experimental units.

Although moisture content of either grain or straw was not recorded at the time of harvest, samples at all locations were taken at the time the wheat crop were harvest ripe or Zadoks growth stage 93 [18]. The moisture content of grain at harvest ripe is between $11 \%$ and $16 \%$ by weight as the standard moisture content for wheat is $13.5 \%$ moisture. The corresponding moisture content of the straw at harvest ripe is similar to that for harvested grain [19, 20]. Both wheat grain and straw can be stored indefinitely at ambient temperatures at the standard moisture content and are not subject to spoilage as long as the samples are kept dry. 
Temperature and precipitation data for each of the location years were compiled ad-hoc using the nearest weather station for which complete records could be found in U.S. Global Historical Climatology Network's daily summaries database [21]. Average maximum and average minimum air temperatures were calculated by averaging the respective daily average maximum and minimum temperature from the day of the trial at an individual location-year was seeded through the day the trial was harvested. The precipitation was reported as the cumulative amount of precipitation between seeding and harvesting for the trial at an individual locationyear.

Data were subjected to the PROC MIXED procedure for ANOVA in SAS [22]. Data pooled across varietal trial entries, replications, and location-years were analyzed. The model contained wheat class and state in which state was treated as a nested effect within wheat class. Least square means were estimated for wheat classes after controlling for the nested effects of state. Means were separated using Fisher's LSD $(\mathrm{P}=0.05)$. It should be noted that the collected data are unbalanced both within and between classes due to the fact that not all classes are represented in each state or location-year where the survey was conducted.

\section{Results and discussion}

HI ranged from 0.33 to 0.61 for the five classes of wheat surveyed in eight states during 2008 to 2010 (Table 3). Soft white wheat generally had higher grain yields than other classes of wheat. The data on HI and grain yield were similar to values reported in the literature [5] and [12]. Regardless of growing environment, SRWW produced the highest HI (0.61) among all wheat classes (Table 3). SRWW also had the lowest straw yield $\left(3.4 \mathrm{tha}^{-1}\right)$ and aboveground biomass $\left(8.6 \mathrm{tha}^{-1}\right)$ but did not produce the highest grain yield. SWWW, DW, HRSW, and SWSW had intermediate HI values, ranging from 0.49 to 0.42 . SWSW and SWWW were the 
most productive in straw (9.6 and $9.4 \mathrm{t} \mathrm{ha}^{-1}$ respectively) and aboveground biomass (16.6 and $17.0 \mathrm{t} \mathrm{ha}^{-1}$ respectively). HRWW had the lowest HI (0.33) and the lowest grain yield $\left(4.1 \mathrm{t} \mathrm{ha}^{-1}\right)$ largely due to their limited biomass production as a result of the limited amount of available moisture in the regions where they were grown. These observations emphasize the importance of combining HI with aboveground biomass as the assessment criterion for straw yield. HI alone indicates the partitioning of biomass not the quantitative productivity. Though strong relations may exist among HI and yield parameters, a high HI does not necessarily suggest high grain yield or low straw yield; and vice versa. Assessment of HI must be based on relatively constant biomass to be meaningful for yield comparisons [11].

Variations in $\mathrm{HI}$ and yield parameters were detected within wheat class. A large difference was found between SWWW grown in ID and OR (Table 4). SWWW grown in OR was $66 \%$ lower in straw yield, $18 \%$ lower in grain yield, and $48 \%$ lower in aboveground biomass, but was $62 \%$ higher in HI, when compared with those grown in ID. This can largely be explained by the low precipitation in the rain fed sites in OR versus the irrigated site near Parma, ID. HRWW grown in OK and TX was consistent in $\mathrm{HI}$ and grain yield but was substantially different in straw yield and aboveground biomass. HRWW grown in OK produced more than twice the straw and aboveground biomass than those grown in TX. Less variability was present among participating states within the HRSW class (Table 4). HRSW grown in AZ had high HI and low straw yield and HRSW grown in ND had low HI and low grain yield, compared to the other three states. Environmental factors including air temperatures and precipitation have been known to exert influence on HI and yields [11], [23], and [24]. Climatic differences among states, particularly available moisture, may thus be a significant contributor to the variability in HI and yield parameters within wheat class as demonstrated by SWWW grown in ID and OR 
(Table 5). The low HI observed in ND in 2009 coincided with severe foliar fungal diseases caused by, Septoria spp. and leaf rust. Therefore it is possible that biotic stresses may also affect HI. Other contributing environmental factors include pest and disease activity. Variations in harvest method and straw yield determination method contributed to the within-class variability as illustrated by the differences within SWWW grown in ID and OR or HRWW grown in OK and TX (Table 2).

Table 3 here.

Table 4 here.

Table 5 here.

As part of the SGI effort, the present study has quantified straw yield and aboveground biomass for five classes of wheat grown in eight states of the United States between 2008 and 2010. Across wheat classes and regions, an average of 1.23 tonnes of straw was produced per ha for every tonnes of grains harvested, which corresponded to an overall HI value of 0.45 . The potential for wheat straw to serve as a feedstock can be approximated by using the average wheat yield within class/ region and multiplying it with class/region specific HI.

The strength of the study lies in the large number of observations and the reasonably consistent practices among the collaborators, which allows for an initial assessment of the genetic and environmental variations among wheat classes.. The unbalanced nature of the data is inevitable because not all classes of wheat are grown in each of the regions/states. Regions/states 
had thus to be analyzed as a nested effect within wheat class. This precludes the examination of the possible interactions between wheat class and growing environment.. Furthermore, the survey was conducted on existing varietal trials rather than trials that were specifically designed to measure the effect of weather on grain and biomass yield. Year-over-year variability in temperatures and precipitation is inherent to dryland cropping and sampling across years accounts for those effects. Average air temperatures were relatively stable across the years for most locations but precipitation fluctuated considerably for some locations, especially Maricopa AZ and Parma ID. However, irrigation supplemented the received precipitation in either year the data was collected in Parma ID to meet crop water needs. The results of this initial survey suggest that additional sampling of either varietal trials or dedicated biomass trials can further refine the estimates presented in this paper.

\section{Conclusion.}

The present study has investigated the potential of wheat straw as a cellulosic ethanol feedstock across the major wheat growing regions in the US by quantifying straw yield and aboveground biomass for five US wheat classes. An overall HI of 0.45 suggests that over half the above ground biomass is potentially available as feedstock annually. However, differences in straw yield and HI were detected among wheat classes and regions. SRWW produced the highest HI and lowest straw yield among wheat classes. SWSW and SWWW produced the highest straw yield. HRWW had the lowest HI. Variations within wheat class are attributable to differences in growing conditions when these trials were conducted, the genetic differences between entries in the individual trials, and differences in cultural practices. Differences in precipitation are likely 
the largest contributor to these observed differences. The major limitation of the study is the limited number of years sampled. Initiation of dedicated biomass trials across classes and regions should allow for more precise estimates and improve the predictive power of the estimated HI and shed more light on the question whether annual differences in precipitation are more important than the overall climatic differences between states within classes. Nonetheless the class specific HI estimated in this study allow for the amount of wheat straw available as cellulosic feedstock in a state or wheat class to be estimated using the grain yields provided by the National Agricultural Statistics Service and the class specific HI with the formula below.

$$
\text { Straw yield }=\left(\frac{1-H I}{H I}\right) \times \text { Grain yield }
$$

\section{Acknowledgements}

Funding for this research was provided by the US Department of Transportation, US Department of Energy, and US Department of Agriculture through the national Sun Grant Initiative administered by South Dakota State University.

\section{References}

[1] Larsen S, Bruun S, Lindedam J. Straw yield and saccharification potential for ethanol in cereal species and wheat cultivars. Biomass Bioenerg 2012;45(1):239-250.

[2] McMillan JD. Bioethanol production: status and prospects. Renew Energ 1997;10(23):295-302. 
[3] Erdei B, Barta Z, Sipos B, Réczey K, Galbe M, Zacchi G. Ethanol production from mixtures of wheat straw and wheat meal. Biotechnol Biofuels 2010;3(16):1-9.

[4] Solomon BD, Barnes JR, Halvorsen KE. Grain and cellulosic ethanol: History, economics, and energy policy. Biomass Bioenerg 2007; 31(6):416-425.

[5] ERS, USDA. Wheat data: Yearbook tables. Available at: http://www.ers.usda.gov/dataproducts/wheat-data.aspx\#25170; 2012 [accessed 07.02.15].

[6] Schell DJ, Torget R, Power A, Walter PJ, Grohmann K, Hinman ND. A technical and economic analysis of acid-catalyzed steam explosion and dilute sulfuric acid pretreatment using wheat straw or aspen wood chips. Appl Biochem Biotechnol 1991;28/29(1):87-97.

[7] Spindler DD, Wyman CE, Grohmann K, Mohagheghi A. Simultaneous saccharification and fermentation of pretreated wheat straw to ethanol strains and $\beta$-glucosidase supplementation. Appl Biochem Biotechnol 1989;20/21(1):529-540.

[8] Wyman CE. Ethanol from lignocellulosic biomass: technology, economics, and opportunities. Bioresource Technol 1994;50(1):3-16.

[9] Atwell WA. An overview of wheat development, cultivation, and production. Cereal Food World 2001;46(2):59-62.

[10] Donald CM. In search of yield. J Aust Inst Agr Sci1962;28(1):171-178.

[11] Donald CM, Hamblin J. The biological yield and harvest index of cereals as agronomic and plant breeding criteria. Adv Agron 1976;28(1):361-411.

[12] Hay RKM. Harvest index: a review of its use in plant breeding and crop physiology. Ann Appl Biol 1995;126(1):197-216. 
[13] Austin RB, Bingham J, Blackwell RD, Evans LT, Ford MA, Morgan CL, Taylor M. Genetic improvements in winter wheat since 1900 and associated physiological changes. J Agr Sci 1980;94(3):675-689.

[14] Engel RE, Long DS, Carlson GR. Predicting straw yield of hard red spring wheat. Agron J 2003;95(6):1454-1460.

[15] Akram M. Growth and yield components of wheat under water stress of different growth stages. Bangladesh J Agr Res 2011;36(3):455-468.

[16] Donaldson E, Schillinger WF, Dofing SM. Straw production and grain yield relationships in winter wheat. Crop Sci 2001;41(1):100-106.

[17] Sun Grant Initiative. Available at: http://www.sungrant.org/ [accessed 01.23.15].

[18] Zadoks JC, Chang TT, Konzak CF. A decimal code for the growth stages of cereals. Weed Research 1974;14(6):415-421.

[19] Pfost HB, Maurer S, Chung D, Milliken GA. P.11 in Summarizing and reporting equilibrium moisture data for grains. St. Joseph: Am. Soc. Agric. Engrs, 1976.

[20] Duggal AK, Muir WE, Brooker, DB. Sorption equilibrium moisture contents of wheat kernels and chaff. 1982. Trans ASABE 1982; 25 (4): 1086-1090

[21] National Climatic Data Center. 2013. GHCN-Monthly Version 3. Available at http://www.ncdc.noaa.gov/ghcnm/v3.php (verified 1 July 2015). National Oceanic and Atmospheric Administration: Asheville NC.

[22] SAS 9.2. SAS Institute. SAS/STAT user's guide. 2009; Version 9.2. SAS Inst., Cary, NC.

[23] Pirmoradian N, Sepaskhah AR. A very simple model for yield prediction of rice under different water and nitrogen applications. Biosystems Eng 2006;93(1):25-34. 
[24] Sinclair TR. Historical changes in harvest index and crop nitrogen accumulation. Crop Sci 1998;38(3):638-643. 
Table 1. Location-year, \#replications, latitude, longitude, planting and harvest dates of the participating states (total $\mathrm{n}=1858$ for 255 cultivars across all locations-years).

\begin{tabular}{lllllll}
\hline State & $\begin{array}{c}\text { Harvest } \\
\text { Year }\end{array}$ & $\begin{array}{c}\text { Location } \\
\text { (\#replications) }\end{array}$ & Latitude & Longitude & $\begin{array}{c}\text { Planting } \\
\text { Date }\end{array}$ & $\begin{array}{c}\text { Harvest } \\
\text { Date }\end{array}$ \\
\hline & & & - ---decimal degree---- & $--------m m / d d / y y--------~$ \\
AZ & 2008 & Maricopa(4) & 33.069 & -111.972 & $01 / 04 / 08$ & $06 / 13 / 08$ \\
AZ & 2009 & Maricopa(3) & 33.069 & -111.972 & $12 / 12 / 08$ & $06 / 04 / 09$ \\
ID & 2008 & Parma(4) & 43.800 & -116.938 & $10 / 11 / 07$ & $08 / 07 / 08$ \\
& 2008 & Parma & 43.800 & -116.938 & $03 / 19 / 08$ & $08 / 07 / 08$ \\
ID & 2009 & Parma(4) & 43.800 & -116.938 & $10 / 07 / 08$ & \\
& 2009 & Parma & 43.800 & -116.938 & $03 / 25 / 09$ & \\
KY & 2008 & Lexington(4) & 38.200 & -84.300 & $10 / 30 / 07$ & $06 / 25 / 08$ \\
KY & 2009 & Lexington(4) & 38.200 & -84.300 & $10 / 22 / 08$ & $06 / 25 / 09$ \\
KY & 2010 & Lexington(4) & 38.200 & -84.300 & $10 / 26 / 09$ & $06 / 22 / 10$ \\
MN & 2008 & Fergus Falls(3) & 46.123 & -96.180 & $04 / 23 / 08$ & $08 / 13 / 08$ \\
MN & 2008 & Oklee(2) & 47.778 & -95.859 & $05 / 07 / 08$ & $08 / 25 / 08$ \\
MN & 2009 & Oklee(3) & 47.778 & -95.859 & $05 / 19 / 09$ & $08 / 27 / 09$ \\
MN & 2009 & Perley(3) & 47.151 & -96.798 & $05 / 19 / 09$ & $08 / 27 / 09$ \\
MN & 2010 & Oklee(3) & 47.778 & -95.859 & $04 / 10 / 10$ & $07 / 26 / 10$ \\
ND & 2008 & Lisbon(3) & 46.330 & -97.658 & $04 / 18 / 08$ & $08 / 14 / 08$ \\
ND & 2009 & Lisbon(3) & 46.330 & -97.658 & $05 / 04 / 09$ & $08 / 27 / 09$ \\
OK & 2008 & Apache(4) & 34.894 & -98.361 & $10 / 11 / 07$ & $06 / 04 / 08$ \\
OK & 2008 & Lahoma(4) & 36.388 & -98.088 & $10 / 25 / 07$ & $06 / 16 / 08$ \\
OR & 2008 & Sherman(3) & 45.485 & -120.712 & $10 / 03 / 07$ & $07 / 23 / 08$ \\
OR & 2008 & Benton(4) & 44.632 & -123.198 & $10 / 25 / 07$ & $08 / 12 / 08$ \\
OR & 2009 & Umatilla(3) & 45.733 & -118.519 & $10 / 21 / 08$ & $07 / 28 / 09$ \\
TX & 2008 & Abilene(3) & 35.494 & -100.024 & $10 / 15 / 07$ & $06 / 13 / 08$ \\
TX & 2008 & Dallam(3) & 36.037 & -102.411 & $10 / 09 / 07$ & $06 / 13 / 08$ \\
\hline & & & & & & \\
\end{tabular}


Table 2. Wheat class, harvest method, and straw determination method of participating states.

\begin{tabular}{|c|c|c|c|c|c|c|}
\hline State & Harvest Year & Location & Wheat Class & $\begin{array}{l}\text { Harvest } \\
\text { Method }\end{array}$ & $\begin{array}{l}\text { Cutting } \\
\text { Height }\end{array}$ & $\begin{array}{c}\text { Straw Yield } \\
\text { Determination }\end{array}$ \\
\hline & & & & & $-\mathrm{cm}-$ & \\
\hline AZ & 2008, 2009 & Maricopa & DW, HRSW & hand harvest & 3 & biomass minus grain \\
\hline ID & 2008, 2009 & Parma & HRSW, SWSW, SWWW & hand harvest & 2 & weighed straw \\
\hline KY & $2008,2009,2010$ & Lexington & SRWW & small combine & 7 & weighed straw \\
\hline \multirow[t]{3}{*}{$\mathrm{MN}$} & 2008 & Fergus Falls, Oklee & HRSW & hand harvest & 2 & biomass minus grain \\
\hline & 2009 & Oklee, Perley & HRSW & hand harvest & 2 & biomass minus grain \\
\hline & 2010 & Oklee & HRSW & hand harvest & 2 & biomass minus grain \\
\hline ND & 2008, 2009 & Lisbon & HRSW & hand harvest & 5 & biomass minus grain \\
\hline OK & 2008 & Apache, Lahoma & HRWW & hand harvest & 2 & biomass minus grain \\
\hline \multirow[t]{2}{*}{ OR } & 2008 & Sherman, Benton & SWWW & small combine & 5 & weighed straw \\
\hline & 2009 & Umatilla & SWWW & small combine & 5 & weighed straw \\
\hline TX & 2008 & Abilene, Dallam & HRWW & small combine & 3 & weighed straw \\
\hline
\end{tabular}


Table 3. Least square means of harvest index among five of the six US wheat classes: Durum wheat (DW), hard red spring wheat (HRSW), hard red winter wheat (HRWW), soft red winter wheat (SRWW), and soft white wheat (SWW). The soft white class was divided in two subclasses based on growth habit: soft white spring wheat (SWSW), and soft white winter wheat (SWWW). Different letters denote significant difference at $\mathrm{P}=0.05$. Data pooled across participating states, varietal trial entries, and location-years are presented (total $n=1858$ for 255 cultivars across all locations-years).

\begin{tabular}{lcccc}
\hline $\begin{array}{c}\text { Wheat } \\
\text { Class }\end{array}$ & $\begin{array}{c}\text { Harvest } \\
\text { Index }\end{array}$ & $\begin{array}{c}\text { Straw } \\
\text { Yield }\end{array}$ & $\begin{array}{c}\text { Grain } \\
\text { Yield }\end{array}$ & $\begin{array}{c}\text { Aboveground } \\
\text { Biomass }\end{array}$ \\
\cline { 3 - 5 } DW & & & $\mathrm{t} \mathrm{ha}^{-1}$ & \\
\cline { 4 - 5 } HRSW & $0.46 \mathrm{c}$ & $7.3 \mathrm{~b}$ & $6.0 \mathrm{c}$ & $13.3 \mathrm{~b}$ \\
HRWW & $0.42 \mathrm{~d}$ & $8.1 \mathrm{~b}$ & $5.7 \mathrm{~d}$ & $13.8 \mathrm{~b}$ \\
SRWW & $0.61 \mathrm{a}$ & $6.1 \mathrm{c}$ & $4.1 \mathrm{f}$ & $10.2 \mathrm{c}$ \\
SWSW & $0.42 \mathrm{~d}$ & $9.6 \mathrm{~d}$ & $5.2 \mathrm{e}$ & $8.6 \mathrm{~d}$ \\
SWWW & $0.49 \mathrm{~b}$ & $9.4 \mathrm{a}$ & $7.6 \mathrm{~b}$ & $16.6 \mathrm{a}$ \\
\hline
\end{tabular}


Table 4. Least square means of harvest index among five of the six US wheat classes: Durum wheat (DW), hard red spring wheat (HRSW), hard red winter wheat (HRWW), soft red winter wheat (SRWW), and soft white wheat (SWW) grown in eight states. The soft white class was divided in two subclasses based on growth habit: soft white spring wheat (SWSW), and soft white winter wheat (SWWW). Different letters denote significant difference at $\mathrm{P}=0.05$. Data pooled across varietal trial entries and location-years are presented (total $n=1858$ for 255 cultivars across all locations-years).

\begin{tabular}{llllll}
\hline $\begin{array}{l}\text { Wheat } \\
\text { Class }\end{array}$ & State & $\begin{array}{c}\text { Harvest } \\
\text { Index }\end{array}$ & $\begin{array}{c}\text { Straw } \\
\text { Yield }\end{array}$ & $\begin{array}{c}\text { Grain } \\
\text { Yield }\end{array}$ & $\begin{array}{c}\text { Aboveground } \\
\text { Biomass }\end{array}$ \\
\hline & & & & \multicolumn{2}{c}{$\mathrm{tha}^{-1}$} \\
\cline { 4 - 6 } DW & AZ & $0.46 \mathrm{c}$ & $7.3 \mathrm{de}$ & $6.0 \mathrm{~d}$ & $13.3 \mathrm{c}$ \\
HRSW & AZ & $0.50 \mathrm{~b}$ & $5.7 \mathrm{ef}$ & $5.7 \mathrm{de}$ & $11.4 \mathrm{de}$ \\
HRSW & ID & $0.42 \mathrm{~cd}$ & $9.1 \mathrm{bc}$ & $6.7 \mathrm{bc}$ & $15.8 \mathrm{~b}$ \\
HRSW & MN & $0.41 \mathrm{~d}$ & $9.5 \mathrm{~b}$ & $6.2 \mathrm{~cd}$ & $15.7 \mathrm{~b}$ \\
HRSW & ND & $0.35 \mathrm{ef}$ & $8.0 \mathrm{~cd}$ & $4.3 \mathrm{f}$ & $12.3 \mathrm{de}$ \\
HRWW & OK & $0.33 \mathrm{f}$ & $8.4 \mathrm{c}$ & $4.2 \mathrm{f}$ & $12.6 \mathrm{~cd}$ \\
HRWW & TX & $0.33 \mathrm{f}$ & $3.8 \mathrm{~g}$ & $4.1 \mathrm{f}$ & $7.9 \mathrm{f}$ \\
SRWW & KY & $0.61 \mathrm{a}$ & $3.4 \mathrm{~g}$ & $5.2 \mathrm{e}$ & $8.6 \mathrm{f}$ \\
SWSW & ID & $0.42 \mathrm{~d}$ & $9.6 \mathrm{~b}$ & $7.0 \mathrm{~b}$ & $16.6 \mathrm{~b}$ \\
SWWW & ID & $0.37 \mathrm{e}$ & $14.1 \mathrm{a}$ & $8.3 \mathrm{a}$ & $22.4 \mathrm{a}$ \\
SWWW & OR & $0.60 \mathrm{a}$ & $4.8 \mathrm{f}$ & $6.8 \mathrm{~b}$ & $11.6 \mathrm{e}$ \\
\hline
\end{tabular}


Table 5. Climatic features for trial location-years in participating states.

\begin{tabular}{|c|c|c|c|c|c|c|c|c|c|c|}
\hline \multirow[t]{3}{*}{ Location } & \multirow[t]{3}{*}{$\begin{array}{c}\text { Approx. } \\
\text { Growing Season }\end{array}$} & \multicolumn{3}{|c|}{$\begin{array}{c}\text { Average Maximum } \\
\text { Air Temperature }\end{array}$} & \multicolumn{3}{|c|}{$\begin{array}{c}\text { Average Minimum } \\
\text { Air Temperature }\end{array}$} & \multicolumn{3}{|c|}{ Precipitation } \\
\hline & & \multicolumn{3}{|c|}{$-{ }^{\circ} \mathrm{C}-$} & \multicolumn{3}{|c|}{${ }^{\circ} \mathrm{C}$} & \multicolumn{3}{|c|}{$-\mathrm{mm}-$} \\
\hline & & 2008 & 2009 & 2010 & 2008 & 2009 & 2010 & 2008 & 2009 & 2010 \\
\hline Maricopa AZ & January-June & 27.6 & 29.3 & - & 8.1 & 9.4 & - & 86 & 29 & - \\
\hline Parma ID ${ }^{\dagger}$ & March-August & 24.4 & 25.1 & - & 7.6 & 8.4 & - & 43 & 108 & 一 \\
\hline Parma ID ${ }^{\dagger}$ & October-August & 15.9 & 16.5 & - & 2.1 & 2.6 & - & 130 & 169 & 一 \\
\hline Lexington $\mathrm{KY}$ & October-August & 14.2 & 14.0 & 14.1 & 5.0 & 4.5 & 5.1 & 1170 & 882 & 781 \\
\hline Fergus Falls MN & May-August & 22.9 & - & - & 11.1 & - & - & 398 & - & - \\
\hline Oklee MN & May-August & 22.6 & 21.7 & 23.4 & 10.1 & 9.9 & 12.5 & 284 & 411 & 457 \\
\hline Perley MN & May-August & - & 22.8 & - & - & 9.3 & - & - & 230 & - \\
\hline Lisbon ND & May-August & 25.1 & 23.6 & - & 11.3 & 10.4 & - & 276 & 269 & - \\
\hline Apache OK & October-June & 22.0 & - & - & 6.3 & - & - & 366 & - & - \\
\hline Lahoma OK & October-June & 19.2 & - & - & 3.2 & - & - & 810 & - & - \\
\hline Benton OR & October-July & 14.4 & - & - & 2.8 & - & - & 1604 & - & - \\
\hline Sherman OR & October-July & 13.3 & - & - & 1.5 & - & - & 196 & - & - \\
\hline Umatilla OR & October-July & - & 15.7 & - & - & 2.4 & - & - & 170 & - \\
\hline Abilene TX & October-July & 22.6 & - & - & 8.0 & - & - & 357 & - & - \\
\hline Dallam TX & October-June & 18.4 & - & - & -0.4 & - & - & 71 & - & - \\
\hline
\end{tabular}

${ }^{\dagger}$ Location with irrigated trial. 